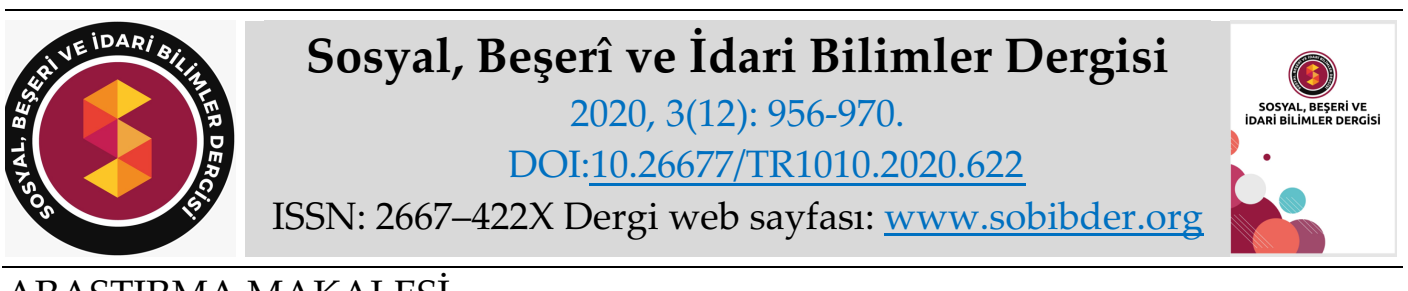

ARAȘTIRMA MAKALESI

\title{
Kamu ve Sivil Toplumda Çalışan Sosyal Hizmet Uzmanlarının Sosyal Adalet Savunuculuğu Düzeylerinin Karşılaştırılması*
}

Rumeysa BOZDEMIR, Sosyal Hizmet Bilim Uzmanı, e-posta: rumeysabozdemir66@gmail.com ORCID: https://orcid.org/0000-0001-9507-2143

Dr. Öğr. Üyesi Esra KILIÇ CEYHAN, Ankara Yıldırım Beyazıt Üniversitesi, Sağlık Bilimleri Fakültesi, Ankara, e-posta: shu esra@hotmail.com

ORCID: https://orcid.org/0000-0002-9853-5788

Öz

$\mathrm{Bu}$ araştırmanın amacı kamu kurum ve kuruluşları ile sivil toplum kuruluşlarında çalışan sosyal hizmet uzmanlarının sosyal adalet savunuculuğu düzeylerini ortaya koymaktır. Nicel araştırma yöntemleri kullanılan verilerin analizinde t-testi, korelasyon ve ANOVA analizleri kullanılmış ve 100 sosyal hizmet uzmanının araştırmaya katılımı sağlanmıştır. Araştırmaya göre sosyal hizmet uzmanlarının sosyal adalet savunuculuğu, işbirlikçi hareket, müracaatçının güçlendirilmesi ve müracaatçı/toplum savunuculuğu düzeyleri yüksek; sosyal/politik savunuculuk düzeyleri orta düzeydedir. Sosyal hizmet uzmanlarının sosyal adalet savunuculuğu ve işbirlikçi hareket düzeyleri kamu kurum ve kuruluşunda ve sivil toplum kuruluşunda çalışma durumuna göre anlamlı bir şekilde farklılaşmaktadır. Ayrıca sosyal adalet savunuculuğu ve alt ölçekleri cinsiyete, bir STK'ya üye olma ve üniversite dişında bir savunuculuk eğitimi alma durumuna göre anlamlı bir şekilde farklılaşmaktadır. Bununla birlikte sosyal adalet savunuculuğu ve alt ölçekleri ile kamuda çalışma süresi ve STK'da çalışma süresi arasında anlamlı bir ilişki bulunmaktadır. Elde edilen sonuçlar doğrultusunda kamu kurum ve kuruluşları ile sivil toplum kuruluşlarında çalışan sosyal hizmet uzmanlarının sosyal adalet savunuculuğu düzeylerini etkileyen etmenlerin araştırılarak; alanın ve sosyal hizmet uzmanlarının güçlendirilmesi ve iyileştirilmesine yönelik çalışmalar yürütülmesi önerilmektedir.

*Bu çalışma "Kamu Kurum ve Kuruluşlarında ve Sivil Toplum Kuruluşlarında Çalışan Sosyal Hizmet Uzmanlarının Sosyal Adalet Savunuculuğu Düzeylerinin Karşılaştırılması“ adlı yüksek lisans çalışmasının verileri kullanılarak hazırlanmıştır.

Anahtar Kelimeler: Kamuda Sosyal Hizmet, Savunuculuk, Sivil Toplumda Sosyal Hizmet, Sosyal Adalet, Sosyal Adalet Savunuculuğu.

Makale Gönderme Tarihi: 28.08.2020

Makale Kabul Tarihi: 01.12.2020

\section{Önerilen Atıf:}

Bozdemir, R. ve Kılıç Ceyhan, E. (2020). Kamu ve Sivil Toplumda Çalışan Sosyal Hizmet Uzmanlarının Sosyal Adalet Savunuculuğu Düzeylerinin Karşılaştırılması, Sosyal, Beşeri ve İdari Bilimler Dergisi, 3(12): 956970.

(C) 2020 Sosyal, Beşerî ve İdari Bilimler Dergisi. 


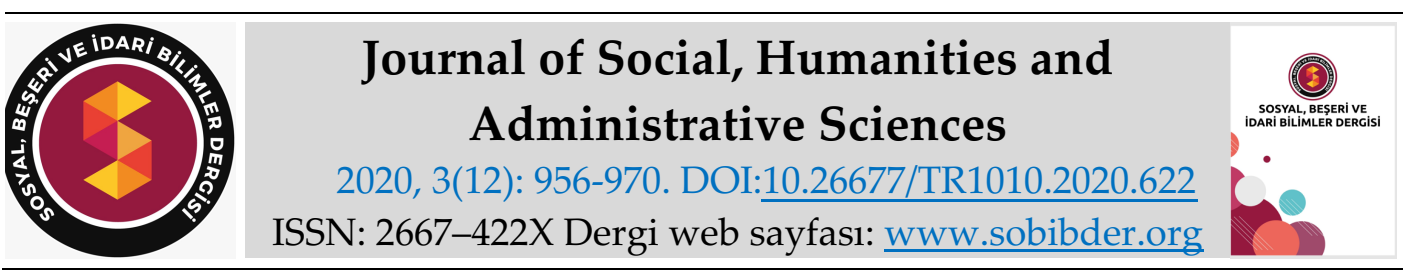

RESEARCH PAPER

\title{
Comparison of Social Justice Advocacy Levels of Social Workers Working in Public Institutions and Non-Governmental Organizations
}

Rumeysa BOZDEMIR, Social Worker, e-mail: rumeysabozdemir66@gmail.com ORCID: https://orcid.org/0000-0001-9507-2143

Assistant Prof. Dr. Esra KILIÇ CEYHAN, Ankara Yıldırım Beyazıt University, Faculty of Health Sciences, Ankara, e-mail: shu_esra@hotmail.com ORCID: https://orcid.org/0000-0002-9853-5788

\begin{abstract}
The aim of this study is to reveal the levels of social justice advocacy of social workers working in public and non-governmental organizations (NGO). In the analysis of the data, quantitative methods of t-test, correlation, and ANOVA analyzes were used, and 100 social workers were participated in the study. Results of study reveal that social workers' social justice advocacy, collaborative action, client empowerment, and client/community advocacy levels are high, and social/political advocacy levels are medium. Accordingly, social justice advocacy and collaborative action levels of social workers differ significantly whether they work in public or non-governmental organizations. In addition, social justice advocacy and the subscales differ significantly according to gender, being a member of an NGO, and receiving advocacy training from outside of the university. Also, there is a significant relationship between social justice advocacy with the subscales and working times in the public and non-governmental sectors. In line with the results obtained, by investigating the factors affecting the social justice advocacy levels of social workers working in public institutions and non-governmental organizations; it is recommended to carry out studies to strengthen and improve the social workers and the field.
\end{abstract}

Keywords: Advocacy, Social Justice, Social Justice Advocacy, Social Work in NGO's, Social Work in Public Sector.

Received: 28.08 .2020

Accepted: 01.12.2020

\footnotetext{
Suggested Citation:

Bozdemir, R. and Kılıç Ceyhan, E. (2020). Comparison of Social Justice Advocacy Levels of Social Workers Working in Public Institutions and Non-Governmental Organizations, Journal of Social, Humanities and Administrative Sciences, 3(12): 956-970.

(c) 2020 Sosyal, Beşerî ve İdari Bilimler Dergisi.
} 


\section{Gíriş}

Sosyal hizmet, sosyal değişimi, sosyal gelişimi, insanların güçlendirilmesini, bireylerin özgürleştirilmesini, sosyal uyumu ve sosyal refahı arttırmayı hedefleyen uygulamaya dayalı akademik bir disiplindir (www.ifsw.org). Sosyal hizmet uzmanları, bireyi çevresi içinde ele alarak mikro, mezzo ve makro düzeyde çalışmalar gerçekleştirir. Birey ve aileyi odağına alan çalışmalar mikro; toplum ve devleti odağına alan çalışmalar makro; mikro ile makro arasında gruplar ve organizasyonları odağına alan çalışmalar ise mezzo düzeyde sosyal hizmet uygulamaları olarak adlandırılırlar (Sheafor ve Horejsi, 2014:27-28).

Sosyal hizmetin amacı, insanların sosyal işlevselliğini artırmaktır. Sosyal işlevsellik, bireylerin toplum içinde kendilerini tanımlayan ve yönlendiren sosyal rollerini başarı ile gerçekleştirmesidir (Sheafor ve Horejsi, 2014:23). Sosyal hizmetin temel değerleri hizmet, sosyal adalet, insan onuru ve değeri, insan ilişkilerinin önemi, dürüstlük ve yeterliliktir. Sosyal hizmet uzmanları, sosyal adalet değeri doğrultusunda adaletsiz uygulamalarla mücadele eder (www.socialworkers.org).

Sosyal hizmetin sosyal adalet değerinden yola çıarak bu araştırmada sosyal hizmet, kamuda ve sivil toplumda sosyal hizmet, sosyal adalet savunuculuğu kavramları üzerinde durulmuş, bu doğrultuda sosyal hizmet uzmanlarının sosyal adalet savunuculuğu düzeyleri değerlendirilmeye çalışılmıştır.

\section{Sosyal Adalet Savunuculuğu}

Sosyal hizmet uzmanları için savunuculuk, onları diğer mesleklerden ayıran temel uygulamalardandır. Yalnızca güncel politikaları değil, bu politikaların oluşma süreçlerini ve etkileyen etmenleri bilmek de önemlidir. Bu bilgiler ışığında sosyal hizmet uzmanları gerekli savunuculuk faaliyetlerini yürütür. Bu nedenle çalıştıkları kurumlar ve uygulamaların yapısı farklılaşsa bile savunuculuğun ilkelerini ve uygulama biçimlerini her sosyal hizmet uzmanının bilmesi ve çalışmalarında uygulaması beklenmektedir (Hoefer, 2016). Savunuculuk faaliyetlerinin kendi içinde çeşitleri vardır. Genelde müracaatçı kitlesinin büyüklügüne göre savunuculuk türleri ortaya çıkmıştır. Bir kişi, aile ya da küçük bir grubun hakları için mücadele vermek vaka savunuculuğu olarak adlandırılmaktadır (Ezell, 2001: 28-29). Yerel ya da merkezdeki herhangi bir politik aktörü boykot, protesto ya da politika yapıcılarla iyi ilişkiler geliştirerek güncel politikayı etkileme girişimleri politika savunuculuğu olarak adlandırılmaktadır (Mosley, 2010a:59). Kimi faaliyetlerde doğrudan bir etkileme hedefi olmadan politik iklimi dişarıdan etkilemek hedeflenmektedir (Mosley, 2011:437). Bu süreçte yalnızca dıştan müdahalelerle değil kamu yetkilileri ile bir araya gelerek, politikayı etkileme sürecinde iş birliği içinde çalışarak içten etkileme taktiği ile de savunuculuk faaliyetleri yürütülmektedir (Mosley, 2010b: 503-532). Ayrıca yalnızca iş birliği içinde uyumlu çalışma taktiği değil daha agresif eylemleri içeren savunuculuk faaliyetleri de kullanılabilmektedir (Mosley, 2011:437).

Sosyal adalet, toplumda var olan nimet ve külfetlerin toplum bireyleri arasında adil bir şekilde paylaştııılmasıdır (Sunal, 2011:286). Bir başka deyişle toplumdaki bireylerin aynı hak, fırsat, sorumluluk ve çıarlara sahip olabilmesi durumudur (Zastrow, 2015:20). Sosyal adalet savunuculuğu mikro düzeyde müracaatçının güçlendirilmesi ve müracaatçı savunuculuğu; mezzo düzeyde topluluk işbirliği ve sistem savunuculuğu; makro düzeyde ise işbirlikçi hareket ve sosyal/politik savunuculuğu içine alır. Sosyal adalet savunuculuğu faaliyetleri bazen 
yararlanıcı adına bazense yararlanıcı ile birlikte yürütülür. Bu faaliyetler yararlanıcı grubunu destekleme veya sisteme müdahale şeklinde gerçekleştirilebilir (Lewis vd., 2018).

\section{Kamu ve Sivil Toplum Alanında Sosyal Adalet Savunuculuğunun Geliştirilmesinde Sosyal Hizmetin Önemi}

Sosyal adalet, hiç şüphesiz yalnızca sosyal hizmet mesleğinin çalışma alanında bulunmamaktadır. Pek çok meslek kendi teori ve uygulamaları ile sosyal adaletin sağlanmasına hizmet edebilir. Ancak sosyal hizmet mesleğinin temel değerlerinden birinin sosyal adalet olması aradaki sıkı ilişkiyi ortaya koymaktadır. Sosyal hizmet, toplumdaki dezavantajlı grupların kendilerini sosyal, psikolojik ve fiziksel yönden geliştirmeleri için fırsat oluşturur (Kesgin, 2016:52). Bu fırsatları oluşturmak sosyal adaleti sağlamanın bir adımıdır. Dolayısıyla toplum ile çalışılan her alanda sosyal adalet savunuculuğunu geliştirmek de sosyal hizmetin hedeflerinden biridir.

Günümüzde sosyal hizmet sadece dezavantajlı gruplara hizmet vermekle sinırlı bir uygulama alanından daha fazlasına sahiptir. Sosyal adaleti sağlama, refah seviyesini yükseltme ve eşitsizliklerle mücadele başta olmak üzere pek çok makro düzeyde değişimi hedefleyen amaçlara sahiptir (Kesgin, 2016:59). Sosyal hizmetin toplumların refah seviyesini yükseltme hedefi, sosyal hizmeti sosyal adaleti sağlama noktasında güçlü bir yere getirmektedir.

Sosyal hizmet çalışmalarında kaynağın büyük çoğunlukla yerel ve merkezi hükümetten sağlanması sebebiyle sosyal hizmet mesleği geçmişten günümüze devlet kurumları ile yakın bir ilişki içinde olmuştur. Bu durumda ister sivil toplumda yapılan ister kamuda yapılan sosyal adalet savunuculuğu çalışmalarında yerel ve merkezi kurumlarla iş birliği çok önemli bir yere sahip olmaktadır (Reamer, 2018: 173-208). İşbirliğinin etkili yürütülmesi şüphesiz sosyal adalet savunuculuğu çalışmalarını da olumlu yönde etkiler.

Sosyal hizmet uzmanları, doğru ve yerinde uygulamalar ile sosyal ve ekonomik politikanın geliştirilmesine çok yönlü ve etkili bir katkı sağlayabilir. Sosyal hizmet uzmanları sahip oldukları profesyonel becerileri ve kaynakları kamuda, sivil toplum kuruluşlarında ve özel sektörde yaptıkları çalışmalarda kullanarak problemlerin çözümünde rol oynayabilir (Rwomire, 2011:116). Sosyal hizmet uzmanının sahip olduğu becerilerin sosyal adaletin geliştirilmesinde bu denli rol alması, sosyal hizmetin bu alandaki etkisini de ortaya çıkarmaktadır. Sosyal hizmetin sosyal adalet savunuculuğu alanındaki etkisini hedefleri, teorileri ve uygulamaları büyük ölçüde etkilemektedir. Sosyal hizmet değerleri doğrultusunda hizmet veren sosyal hizmet uzmanları sosyal adalet savunuculuğu noktasında önemli bir rol üstlenmektedir.

\section{Araştırmanın Amacı}

$\mathrm{Bu}$ araştırmanın amacı, kamu kurum ve kuruluşları ile sivil toplum kuruluşlarında çalışan sosyal hizmet uzmanlarının sosyal adalet savunuculuğu düzeylerini ortaya koymaktır. Ayrıca, kamu kurum ve kuruluşlarında ya da sivil toplum kuruluşlarında çalışıyor olmanın sosyal adalet savunuculuğunda anlamlı bir farklılaşmaya yol açıp açmadığını belirlemektir. Bununla birlikte uzmanların sosyal adalet savunuculuğu düzeylerini tanıtıcı bilgiler ve mesleki faaliyetlere ilişkin bilgileri dikkate alarak değerlendirmek amaçlanmaktadır. 


\section{YÖNTEM}

\section{Araştırmanın Modeli}

Araştırmada nicel araştırma yöntemlerinden ilişkisel tarama modeli kullanılmıştır. İlişkisel tarama modeli iki ya da daha fazla değişken arasındaki ilişkinin ölçüldüğü araştırma modelidir. Bu ilişki değişkenler arasında korelasyon veya karşılaştırmaya bakılarak ortaya konmaya çalışılır (Karasar, 1995:81).

\section{Evren ve Örneklem}

Araştırmada seçkisiz olmayan örneklem yöntemlerinden amaçsal örneklem kullanılmıştır. Amaçsal örnekleme belli ölçütleri karşılayan bir çalışma grubu ile çalışılmak istendiğinde kullanılan ve derinlemesine araştırma yapılmasına olanak sağlayan bir örnekleme yaklaşımıdır (Büyüköztürk vd., 2014:90). Bu araştırmada kamu kurum ve kuruluşlarında ve sivil toplum kuruluşlarında çalışan sosyal hizmet uzmanları ile çalışılmıştır.

Araştırmanın evreni kamu kurum ve kuruluşlarında ve sivil toplum kuruluşlarında çalışan sosyal hizmet uzmanlarından oluşmaktadır. Araştırmanın çalışma evrenini Ankara ilinde kamu kurum ve kuruluşları ve sivil toplum kuruluşlarında çalışan sosyal hizmet uzmanları oluşturmaktadır. Toplumbilimlerinde yapılacak araştırmalarda genellikle örneklem çekmenin alt limiti olarak 100 sayısı alınabilir (Aziz, 2014:56). Örneklem, çalışma evreninden seçilen ve çalışmaya gönüllü katılım sağlayan 100 sosyal hizmet uzmanından oluşmaktadır.

\section{Veri Toplama Araçları}

Araştırmada veri toplama aracı olarak katılımcılara ilişkin tanıtıcı bilgilerin, katılımcıların mesleki faaliyetlerine ve sosyal adalet savunuculuğu faaliyetlerine ilişkin bilgilerin toplandığ 1 anket formu; katılımcıların sosyal adalet savunuculuk düzeylerini ölçmeyi sağlayan Sosyal Adalet Savunuculuğu Ölçeği kullanılmıştır.

\section{Anket Formu}

Anket formu "Tanıtıcı Bilgiler, Mesleki Faaliyetlere İlişkin Bilgiler, Sosyal Adalet Savunuculuğu Faaliyetlerine İlişkin Bilgiler" isimli üç ana bölümden oluşmaktadır. Tanıtıcı bilgiler bölümünde 5 , mesleki faaliyetlere ilişkin bilgiler bölümünde 15 ve sosyal adalet savunuculuğu faaliyetlerine ilişkin bilgiler bölümünde 12 olmak üzere anket formunda toplamda 32 soru bulunmaktadır.

\section{Sosyal Adalet Savunuculuğu Ölçeği}

Sosyal adalet savunuculuğu ölçeği, Dean (2009) tarafından geliştirilmiş ve 2014 yılında Serpen, Duyan ve Aldoğan tarafından geçerlilik ve güvenirlik çalışması gerçekleştirilmiştir (Serpen vd., 2014). Ölçek, meslek elemanlarının sosyal adalet savunuculuğu için gerekli beceri ve yetkinliklerini ölçmek amacıyla kullanılmaktadır.

Orijinalinde 43 maddeden oluşan ölçek, geçerlik ve güvenirlik çalışması sonucu 41 maddeden oluşan son halini almıştır. Ölçek; İşbirlikçi Hareket, Müracaatçının Güçlendirilmesi, Sosyal/Politik Savunuculuk ve Müracaatçı Toplum Savunuculuğu alt ölçeklerinden oluşmaktadır. Orijinal ölçekte 4, 6, 11, 16, 17, 38, 39 ve 41 numaralı maddeler ters kodlanmıştır. Ölçekte maddelere verilen yanıtlarda 1 en düşük 7 en yüksek değeri ifade etmektedir. Ölçeğe göre toplam puan arttıkça sosyal adalet savunuculuk düzeyi/yetkinliği artmaktadır. Katılımcların Sosyal Adalet Savunuculuğu Ölçeği (SAS)'nden alabileceği en düşük puan 41 ve en yüksek puan $287^{\prime}$ dir. 
Tablo 1. Ölçeğin Uyarlama Çalışmasında Bulunan Cronbach Alpha Katsayısı Değerleri

\begin{tabular}{|l|l|}
\hline Ölçek & Cronbach Alpha Katsayısı \\
\hline Sosyal Adalet Savunuculuğu Ölçeği & 0.92 \\
\hline İşbirlikçi Hareket Alt Ölçeği & 0.89 \\
\hline Müracaatçının Güçlendirilmesi Alt Ölçeği & 0.76 \\
\hline Sosyal/Politik Savunuculuk Alt Ölçeği & 0.79 \\
\hline Müracaatçı/Toplum Savunuculuğu Alt Ölçeği & 0.71 \\
\hline
\end{tabular}

Tablo 1'de belirtildiği üzere ölçeğin uyarlama çalışmasında cronbach alpha katsayısı Sosyal Adalet Savunuculuğu Ölçeği için 0.92; İşbirlikçi Hareket Alt Ölçeği için O.89; Müracaatçının Güçlendirilmesi Alt Ölçeği için 0.76; Sosyal/Politik Savunuculuk Alt Ölçeği için 0.79; Müracaatçı/Toplum Savunuculuğu Alt Ölçeği için 0.71 olarak bulunmuştur.

Tablo 2. Araştırma Sonucunda Bulunan Cronbach Alpha Katsayısı Değerleri

\begin{tabular}{|l|l|}
\hline Ölçek & Cronbach Alpha Katsayısı \\
\hline Sosyal Adalet Savunuculuğu Ölçeği & 0.90 \\
\hline İşbirlikçi Hareket Alt Ölçeği & 0.89 \\
\hline Müracaatçının Güçlendirilmesi Alt Ölçeği & 0.78 \\
\hline Sosyal/Politik Savunuculuk Alt Ölçeği & 0.70 \\
\hline Müracaatçı/Toplum Savunuculuğu Alt Ölçeği & 0.51 \\
\hline
\end{tabular}

$\mathrm{Bu}$ araştırmada da güvenirliği belirlemek amacıyla iç tutarlılık analizi yapılmıştır. Tablo 2'ye göre Sosyal Adalet Savunuculuğu Ölçeği için cronbach alpha katsayısı 0.90; İşbirlikçi Hareket Alt Ölçeği için 0.89; Müracaatçının Güçlendirilmesi Alt Ölçeği için 0.78; Sosyal/Politik Savunuculuk Alt Ölçeği için 0.70; Müracaatçı/Toplum Savunuculuğu Alt Ölçeği için 0.51 olarak bulunmuştur.

\section{Verilerin Toplanması ve Analizi}

Veri toplama araçları, araştırmacı tarafından katılımcılara yüz yüze görüşme tekniği ve e-posta aracılığıyla uygulanmıştır. Elden edilen veriler bilgisayar ortamında, SPSS 22 (Statistical Package for Social Sciences) paket programı kullanılarak analiz edilmiştir. Veriler analiz edilirken bağımsız örneklemler t-testi, ilişkisiz örneklemler için tek yönlü ANOVA analizi ve korelasyon analizi yapılmıştır.

\section{BULGULAR ve TARTIŞMA}

Araştırmaya katılan 100 sosyal hizmet uzmanının cinsiyet dağılımlarına bakıldığında \%71'inin kadın ve \%29'unun erkek olduğu görülmektedir. Araştırmaya katılan sosyal hizmet uzmanlarının yaş dağılımlarında yarısından fazlasını (\%64) 26 yaş ve altı, dörtte biri (\%25) 27-32 yaş arası ve kalanının (\%11) 33 yaş ve üstü olduğu görülmektedir. Katılımcıların yaş ortalaması 27,59 iken katılımcılar arasında en düşük yaş 22 en yüksek yaş 50'dir. Araştırmaya katılan sosyal hizmet uzmanlarının çoğunluğu (\%78) lisans programından, \%20'si yüksek lisans programından ve \%2'si doktora programından mezun olduğunu belirtmektedir.

Katılımcıların \%51'i kamu kurum ve kuruluşunda ve \%49'u sivil toplum kuruluşunda görev yaptığını belirtmektedir. Katılımcıların \%55'i herhangi bir sivil toplum kuruluşuna üye iken $\% 45$ 'i bir sivil toplum kuruluşuna üye değildir. Katılımcıların \%60'ı üniversite dışında bir 
savunuculuk eğitimi almadığını belirtirken, \%40'ı üniversite eğitimi dışında bir savunuculuk eğitimi aldığını belirtmektedir.

Tablo 3. SAS, İHÖ, MGÖ, SSÖ ve MSÖ Puanları Betimsel Analizi

\begin{tabular}{|l|l|l|l|}
\hline Ölçek & Min-Max & Ortalama(X) & $\begin{array}{l}\text { Standart Sapma Değeri } \\
\text { (SD) }\end{array}$ \\
\hline SAS & $175-280$ & 223,7900 & 23,68194 \\
\hline İHÖ & $73-119$ & 97,5400 & 11,29353 \\
\hline MGÖ & $41-63$ & 53,6800 & 5,04301 \\
\hline SSÖ & $13-52$ & 32,2600 & 8,43229 \\
\hline MSÖ & $28-49$ & 40,3100 & 4,59621 \\
\hline
\end{tabular}

Sosyal Adalet Savunuculuğu Ölçeği İşbirlikçi Hareket, Müracaatçının Güçlendirilmesi, Sosyal/Politik Savunuculuk ve Müracaatçı Toplum Savunuculuğu alt ölçeklerinden oluşmaktadır. Araştırmadan elde edilen bulgulara göre sosyal hizmet uzmanlarının sosyal adalet savunuculuğu, işbirlikçi hareket, müracaatçının güçlendirilmesi ve müracaatç//toplum savunuculuğu düzeyleri yüksek sosyal/politik savunuculuk düzeyleri orta düzeydedir.

Sosyal hizmet uzmanlarının sosyal adalet savunuculuğu ölçeği ortalama puanları $X=223,79$ 'dir (Tablo 3). Bu durum sosyal hizmet uzmanlarının sosyal adalet savunuculuğu düzeylerinin yüksek olduğu şeklinde yorumlanabilir. Bu çalışmada sosyal hizmet uzmanlarının sosyal adalet savunuculuğu düzeylerinin yüksek olması ümit verici olmakla birlikte 2010 yılında yapılan sosyal hizmet uzmanlarının sosyal hizmet değerlerini mesleki uygulamalarına aktarışı üzerine yapılan nitel bir araştırmada sosyal hizmet uzmanlarının sosyal adalet değerini uygulamaya aktarımının sınırlı olduğu sonucuna ulaşılmıştır (Karabekir, 2010:235). Bu durumda ilerleyen çalışmalarda bu konunun daha detaylı incelenmesinin ve söylemlerle uygulamanın tutarlılığının üzerinde durulmasının önemli olduğu düşünülmektedir.

Sosyal hizmet uzmanlarının işbirlikçi hareket alt ölçeği ortalama puanları $X=97,54$ ' tür (Tablo 3). Bu durum sosyal hizmet uzmanlarını işbirlikçi hareket yeterliliklerinin yüksek olduğu şeklinde yorumlanabilir. Sosyal Hizmet Uzmanları Derneği'nin yayınlandığı etik ilkelerde sosyal hizmet uzmanlarının meslektaşlarına ve diğer meslek elemanlara karşı sorumlulukları olduğu ve bunlardan birinin de disiplinler arası iş birliği olduğu belirtilmiştir. Buna göre sosyal hizmet uzmanları farklı disiplinlerle saygı çerçevesinde çalışmalı ve ortak çalışılan alanda sosyal hizmet bakış açısını ortaya koymalıdır (Duyan vd., 2008:220). Bu durumda gerek kamuda çalışan gerekse sivil toplumda çalışan sosyal hizmet uzmanlarının gelişmiş bir işbirlikçi hareket yeterliliğine sahip olması sosyal hizmetin etik ilkeleri ile oldukça uyumludur.

Sosyal hizmet uzmanlarının müracaatçının güçlendirilmesi alt ölçeği ortalama puanları $X=$ 53,68'dir (Tablo 3). Bu durum sosyal hizmet uzmanlarının müracaatçı güçlendirilmesi yeterliliklerinin yüksek olduğu şeklinde yorumlanabilir. Buna paralel olarak sosyal hizmet öğrencilerinin sosyal adalet savunuculuğu yetkinlikleri ile LGBTI+ bireylere yönelik tutumları arasındaki ilişkinin incelendiği 2016 yılında yapılan bir çalışmada da sosyal hizmet öğrencilerinin müracaatçının güçlendirilmesi yetkinliklerinin yüksek olduğu sonucuna ulaşılmıştır (Kalaycı, 2016:123). Bireyler ya da topluluklar bulundukları sosyoekonomik sistem içinde ya da yasalar karşısında kendini güçsüz hissedebilir. Bu duruma hassas gruplarda daha sık rastlanabilir. Sosyal hizmet uzmanları bu durumda insan temelli program ve kaynaklar aracılığıyla kendilerini ve müracaatçılarını sorun çözme konusunda sosyal hizmete has bir üslupla güçlendirirler (Parsons, 1991:12). Araştırmada sosyal hizmet uzmanlarının müracaatçının güçlendirilmesi 
noktasında yüksek yeterliliğe sahip çıkması uygulamalarında güçlendirme yaklaşımını esas aldıkları şeklinde yorumlanabilir.

Sosyal hizmet uzmanlarının sosyal/politik savunuculuk alt ölçeği ortalama puanları $X=32,26$ 'dır (Tablo 3). Bu durum sosyal hizmet uzmanlarının sosyal/politik savunuculuk yeterliliklerinin orta düzeyde olduğu şeklinde yorumlanabilir. 2018 yılında yayınlanan insan hakları ve sosyal adalet açısından devletin çocuklara ve kadınlara yönelik sunduğu hizmetler konulu doktora çalışmasında o dönemki ismiyle Aile ve Sosyal Politikalar Bakanlığı'nda çalışan sosyal hizmet uzmanı, psikolog, sosyolog, öğretmen ve çocuk gelişimcilerin sosyal adalet savunuculuğu düzeyleri ölçülmüş ve çoğunluğunu sosyal hizmet uzmanlarının oluşturduğu katılımcıların sosyal/politik savunuculuk düzeyleri diğer alt boyutlara oranla en düşük olarak bulunmuştur (Reçber, 2018:174).

Sosyal/politik savunuculuk, kamusal alan düzeyinde yapılan savunuculuk faaliyetlerindendir. Kamusal alan düzeyinde savunuculuk ise toplumun bilinçlendirilmesinden, toplum liderleri ve yöneticileri ile değişim için çalışmayı içeren çok geniş bir savunuculuk alanıdır. Bu alanda savunuculuk faaliyetleri yürütmek politikada veya mevzuatta yer alan ve müracaatçı topluluğunu zor duruma düşüren kanun ve kuralları değiştirmek üzere çalışmalar yürütmek anlamina gelmektedir (Ratts vd., 2007; Toporek vd., 2009). Bu noktada sosyal hizmet uzmanlarının sosyal/politik savunuculuk düzeylerinin orta düzeyde olmasının önemli olduğu ancak yüksek düzeyde olması için de çalışmaların yürütülmesi gerektiği düşünülmektedir. Diğer savunuculuk türlerinin hepsinde yüksek düzeyde savunuculuk yeterliliğine sahipken sosyal/politik savunuculukta orta düzeyde bir yeterliliğe sahip olmaları dikkate değerdir. Bunun nedenlerinin araştırılmasının sosyal/politik savunuculuğu artırmak noktasında önemli bir başlangıç sunacağı düşünülmektedir. Bu çalışmada uygulanan ankette sosyal hizmet uzmanlarına sosyal adalet savunuculuğu yaparken karşılaştıkları güçlükler sorulduğunda verilen en sık yanıtın bürokrasi ve hiyerarşi, sonrasında ise mevzuat ve politika olması ise bu noktada küçük ipuçları sunabilir.

Sosyal hizmet uzmanlarının müracaatçı/toplum savunuculuğu alt ölçeği ortalama puanları $X=$ 40,31'dir (Tablo 3). Bu durum sosyal hizmet uzmanlarının müracaatçı/toplum savunuculuğu düzeylerinin yüksek olduğu şeklinde yorumlanabilir. Bunun aksine sosyal hizmet öğrencilerinin sosyal adalet savunuculuğu yetkinlikleri ile LGBTI+ bireylere yönelik tutumları arasındaki ilişkinin incelendiği 2016 yılında yapılan bir çalışmada ise sosyal hizmet öğrencilerinin müracaatçı/toplum savunuculuğu düzeyleri düşük olarak bulunmuştur (Kalayc1, 2016:122). Bu farklılık öğrencilerin henüz yeterli alan deneyimine sahip olmamasından kaynaklı olabilir. Nitekim 2015 yılında sosyal hizmet öğrencilerinin yaşlı müracaatçılarla çalışma ve yaşlılara yönelik tutumlarının belirlenmesi üzerine yapılan bir araştırmada da yaşlı bireylerle çalışan sosyal hizmet öğrencilerinin yaşlı bireylerle çalışma deneyimi olmayanlara göre yaşlılara karşı daha olumlu tutum sergiledikleri görülmüştür (Mancillk, 2015).

Savunuculuk çalışmalarında bazen müracaatçının kendi kendini gerçekleştirmesi teşvik edilirken bazen de müracaatçı adına savunuculuk faaliyetleri yürütülmektedir. Bu durum müracaatçı düzeyinde müdahalenin altında yer almaktadır (Toporek vd., 2009:262). Sosyal hizmet uzmanlarının müracaatçı/toplum savunuculuğu düzeylerinin yüksek olmasının savunuculuk yetkinlikleri açısından çok önemli olduğu düşünülmektedir.

Araştırmada sosyal hizmet uzmanlarının sosyal adalet savunuculuğunun, işbirlikçi hareketin, müracaatçının güçlendirilmesinin, sosyal/politik savunuculuğun cinsiyete göre $(t=1.061, p=.291$; $\mathrm{t}=1.127, \mathrm{p}=.263 ; \mathrm{t}=1.482, \mathrm{p}=.141 ; \mathrm{t}=-.533, \mathrm{p}=.595)$ ve yaş gruplarına göre $(\mathrm{F}=1.008, \mathrm{p}=.369 ; \mathrm{F}=2.416$, 
$\mathrm{p}=.095 ; \mathrm{F}=1.629, \mathrm{p}=.202 ; \mathrm{F}=.059, \mathrm{p}=.943)$ anlamlı bir şekilde farklılaşmadığ görülmüştür. 2012 yılında sosyal hizmet öğrencilerinin maneviyatı ile sosyal adalet savunuculuğu arasındaki ilişkiyi ölçen bir araştırmada bu bulguya benzer olarak cinsiyetin ve yaşın sosyal adalet savunuculuğu yetkinlikleri üzerinde anlamlı bir farklılık oluşturmadığı görülmüştür (Prior ve Quinn, 2012:183). Aynı şekilde psikoloji mezunlarının danışmanlık eğitimi ve sosyal adalet savunuculuğu yetkinlikleri arasındaki ilişki üzerine 2005 yılında yapılan bir araştırmada da cinsiyet ve yaş gruplarının sosyal adalet savunuculuğu üzerinde anlamlı bir farklılık oluşturmadığ1 görülmüştür (Nilsson ve Schmidt, 1970:273-275). 2019 y1lında sosyal hizmet öğrencilerinin sosyal adalet savunuculuğu yetkinlikleri ile çocuk ihmal ve istismarına bakış açıları arasındaki ilişkilerin incelenmesi amacıyla yapılan bir çalışmada da cinsiyetin sosyal adalet savunuculuğu üzerinden anlamlı bir fark oluşturmadığı bulunmuştur. Ancak yaş grupları arasında anlamlı bir farklılık oluştuğu görülmüştür (Eren, 2019:110). Cinsiyetin sosyal adalet savunuculuğu üzerinde anlamlı bir fark oluşturmaması sosyal hizmet uzmanlarının sosyal hizmetin etik değerlerinden olan sosyal adaleti cinsiyetten bağımsız olarak benimsediğini göstermektedir (www.socialworkers.org). $\mathrm{Bu}$ durum sosyal hizmet uzmanlarının sosyodemografik özellikleri farklılaşsa da etik değerler noktasında profesyonel bir duruş sergileyebildiği şeklinde yorumlanabilir.

Sosyal hizmet uzmanlarının kamuda çalışma süresi arttıkça sosyal adalet savunuculuklarının, işbirlikçi hareketlerinin, müracaatçının güçlendirilmesi düzeylerinin azaldığı görülmüştür ( $\mathrm{r}=-$ .227, $\mathrm{p}=.023 ; \mathrm{r}=-.308, \mathrm{p}=.002 ; \mathrm{r}=-.227, \mathrm{p}=.023$ ). Araştırmada aynı zamanda sosyal hizmet uzmanlarının toplam çalışma süresi arttıkça işbirlikçi hareket düzeyinin azaldığı görülmüştür. $\mathrm{Bu}$ durum deneyim arttıkça mesleki yorgunluğun da biriktiği ve savunuculuk faaliyetlerine ilişkin heyecanın azaldığı şeklinde yorumlanabilir. Çalışma süresi arttıkça olumlu ve olumsuz deneyim de çoğalmaktadır. Bu deneyimlerin kişinin sosyal adalet savunuculuğu faaliyetleri üzerinde olumsuz bir etkisi olabilir. 2018 yılında yapılan sosyal hizmet kurumu çalışanlarında tükenmişlik düzeyini araştıran bir çalışmada 11 yıl ve üzeri deneyime sahip olan meslek elemanlarının tükenmişlik düzeyinin 1-5 yıl arası deneyime sahip olan meslek elemanlarından yüksek olduğu görülmüştür (Çağlıyan, 2018:67). Alanda daha uzun süre çalışanların tükenmişlik düzeyi daha yüksek olduğu gibi, çalışma süresi arttıkça savunuculuk düzeyleri de azalmaktadır. Meslekte geçirilen yılın meslek elemanlarının yeterliliklerini etkilemesi insan ile çalışan sosyal hizmet gibi alanlarda göz ardı edilemeyecek bir öneme sahiptir. Bu nedenle ileride bu durumun çözümüne yönelik çalışmaların gerçekleştirilmesinin önemli olduğu düşünülmektedir.

Kamuda çalışılan sürede görülen ilişkinin aksine Sivil Toplum Kuruluşlarında (STK) çalışılan süre ile sosyal adalet savunuculuğu arasında ise anlamlı bir ilişki bulunamamıştır $(r=.195$, $\mathrm{p}=.052$ ). Bunun sebebi STK'da çalışan ve araştırmaya katılan sosyal hizmet uzmanlarının daha genç olması ve dolayısıyla mesleki deneyimlerinin daha sınırlı olması olabilir. Çünkü araştırmaya katılan kamuda çalışan en deneyimli sosyal hizmet uzmanının 24 yıl deneyimi varken, sivil toplumda çalışan en deneyimli sosyal hizmet uzmanının 8 yıl deneyimi bulunmaktadır. 2015 yılında sosyal hizmet uzmanlarının sorun çözme becerileri üzerine yapılan bir araştırmada da sosyal hizmet uzmanlarının hizmet süresi arttıkça problem çözme becerisinin de arttığı bulunmuştur (Koç, 2015). Yine 2019 yılında çocuk refahı alanında çalışan meslek elemanlarının psikolojik dayanıklılıkları ve baş etme tarzlarının araştıııldığı bir araştırmada da mesleki deneyim arttıkça aktif başa çıma yöntemlerini kullanma durumları da arttı̆̆ görülmüş̧ür (Genç, 2019). Bu durum bizim çalışmamıza da paralel olarak alanda geçirilen sürenin beceri ve yetkinlikler üzerindeki önemini ortaya koymaktadır. 
Diğer alt ölçeklerin aksine sosyal hizmet uzmanlarının sosyal/politik savunuculuk düzeyinin STK'da çalışma süresi arttıkça arttığı görülmüştür $(\mathrm{r}=.244, \mathrm{p}=.014)$. Bu durum alanda kazanılan deneyimin, öğrenme sürecinin sosyal/politik savunuculuk yeterliliğini de artırdığı şeklinde yorumlanabilir. 2019 yılında toplum ruh sağllğı merkezinde çalışan sağllk profesyonellerinin bilgi, beceri, deneyim ve görüşlerinin değerlendirilmesi üzerine yapılan nitel bir araştırmada psikolog, psikiyatrist ve sosyal hizmet uzmanı olmak üzere bazı meslek grupları ile görüşmeler gerçekleştirilmiştir. Görüşmeler sonucunda meslek elemanlarının ruh sağlı̆̆ı alanına ilişkin bilgi ve becerilerini büyük çoğunlukta deneyim sonucunda elde edildiği yorumuna ulaşılmıştır (Akgün, 2019). Bu durum bizim çalışmamızdaki bulgularla paralellik göstermektedir. Çünkü sivil toplum kuruluşlarının toplumları ilgilendiren konularda savunucu ve devlet mekanizmalarını harekete geçirici rolü bulunmaktadır (Kara, 2019:155-169). Bu bağlamda sivil toplum kuruluşlarında geçirilen süre ve alandan kazanılan deneyim arttıkça sosyal hizmet uzmanlarının sosyal/politik savunuculuk yetkinliklerinin de artması olağan olarak yorumlanabilir.

STK'da çalışan sosyal hizmet uzmanlarının sosyal adalet savunuculuklarının ve işbirlikçi hareket düzeylerinin kamu kurum ve kuruluşunda çalışan sosyal hizmet uzmanlarından daha yüksek olduğu görülmüştür ( $t=-2.305, p=0.24 ; t=-2.638, p=0.10)$. Bu duruma sebep olan etken ya da etkenlerin ne olduğu bu çalışmada belirlenmemiştir. İleride yapılacak çalışmalarda sivil toplum alanında çalışan sosyal hizmet uzmanlarının sosyal adalet savunuculuğu ve işbirlikçi hareket düzeylerinin daha yüksek çıkmasına etki eden etmenler araştırılabilir. Bu araştırmada sivil toplum ve kamu arasında farklılaşma bulunmasına karşın, 2016 yılında yayınlanan çocuk refahı alanında çalışan sosyal hizmet uzmanlarının savunuculuk uygulamalarını inceleyen nitel bir araştırmada ise özellikle belli bir kurumda çalışmanın savunuculuk faaliyetlerini olumlu ya da olumsuz olarak etkilemediği belirtilmiştir. Çalışmada savunuculuk faaliyetlerinin kamuda, sivil toplumda ve özel sektörde gerçekleştirmenin kendi içinde avantajları ve dezavantajları olduğu sonucuna ulaşılmıştır. Kamuda çalışan sosyal hizmet uzmanları kamuda çalışmanın savunuculuk faaliyetlerine bir noktada sınırlılık getirse de mevzuatı değiştirme fırsatı, yetki ve güç verdiğini de belirtmiştir. Sivil toplum kuruluşlarında çalışanlar ise her sivil toplum örgütünün aynı imkanları sağlamasa da çoğunlukla savunuculuk faaliyetlerini kolaylaştırdığı belirtmiştir (Karabekir, 2016:306).

Kamuda veya STK'da çalışma durumunun sosyal/politik savunuculuk, müracaatçının güçlendirilmesi ve müracaatçı/toplum savunuculuğu üzerinde anlamlı bir fark oluşturmadığ görülmüştür ( $\mathrm{t}=-1.437, \mathrm{p}=.154 ; \mathrm{t}=-1.148, \mathrm{p}=.254 ; \mathrm{t}=-1,446, \mathrm{p}=.152)$. Bu durum sosyal hizmet uzmanlarının çalıştığı kurumun yapısı ne olursa olsun müracaatçının güçlendirilmesi ve müracaatç//toplum savunuculuğunu gerçekleştirmesi noktasında değerlidir. Çünkü sosyal hizmet uzmanlarının müracaatçının güçlendirilmesi ve müracaatç//toplum savunuculuğu düzeylerinin yüksek olduğu görülmüştür (Tablo 3). Sosyal hizmet uzmanlarının sosyal/politik savunuculuklarının orta düzeyde çıması ise sosyal hizmet uzmanlarının hangi kurumda çalışırsa çalışsın bazı içsel ve dışsal faktörlerden aynı şekilde etkilendiği şeklinde yorumlanabilir. $\mathrm{Bu}$ faktörleri sosyal hizmet uzmanları karşılaştıkları güçlükler kısmında başlıca şu şekilde belirtmiştir: bürokrasi ve hiyerarşi, sistemin yavaş olması, sistemin savunuculuk faaliyetlerini desteklememesi, yasalar, mevzuat, politika, kaynak yetersizliği.

Bir STK'ya üye olan sosyal hizmet uzmanlarının sosyal adalet savunuculuk düzeyi, işbirlikçi hareket düzeyi, müracaatçıyı güçlendirme düzeyi bir STK'ya üye olmayanlardan daha yüksektir $(\mathrm{t}=2.634, \mathrm{p}=.010 ; \mathrm{t}=2.323, \mathrm{p}=.022 ; \mathrm{t}=2.643, \mathrm{p}=.010)$. Bu durumun sivil toplum kuruluşlarında var olan "örgüt" anlayışı ile ilgili olabileceği düşünülmektedir (Karadağ, 2017). Ancak bir STK'da 
gönüllü çalışmalar yapıp yapmama durumu sosyal adalet savunuculuk düzeyi üzerinde anlamlı bir farklılık oluşturmamıştır ( $\mathrm{t}=1.658, \mathrm{p}=.100)$. Bir STK'ya üye olan sosyal hizmet uzmanlarının sosyal/politik savunuculuk düzeyi bir STK'ya üye olmayanlardan daha yüksektir $(\mathrm{t}=2.980$, $\mathrm{p}=.004$ ). Sivil toplumun sosyal, toplumsal ve siyasal olaylara karşı aksiyon alan kurumlar olduğu düşünüldüğünde bu durumun tutarlı olduğu yorumu yapılabilir.

Araştırmada üniversite dışında bir savunuculuk eğitimi alıp almama durumunun sosyal hizmet uzmanlarının sosyal adalet savunuculuğu düzeyi üzerinde anlamlı bir farklılık oluşturmadığı görülmüştür ( $\mathrm{t}=1.700, \mathrm{p}=0.92)$. Ancak üniversite dışında bir savunuculuk eğitimi alan sosyal hizmet uzmanlarının işbirlikçi hareket düzeylerinin böyle bir eğitim almayanlardan daha yüksek olduğu görülmüştür ( $\mathrm{t}=2.300, \mathrm{p}=.024)$. Buna paralel olarak, 2018 yılında yapılan bir araştırmada eğitim sürecinde insan hakları ile ilgili bir ders alan sosyal hizmet uzmanı, psikolog, sosyolog, öğretmen ve çocuk gelişimcilerden oluşan meslek elemanlarının işbirlikçi hareket düzeyleri daha yüksek çıkmıştır. Aynı çalışmada çocuk hakları ile ilgili ders alanların da işbirlikçi hareket düzeyleri daha yüksek çımıştır (Reçber, 2018:180). Bu durumun savunuculuk alanına giren konularda eğitim almanın önemini ortaya koyduğu düşünülmektedir.

Sosyal hizmet uzmanlarının sosyal adalet savunuculuğu düzeyleri mesleği kendi isteğiyle tercih etme, çalışılan sosyal hizmet alanı, alınan maaşı yeterli bulma, yaptığı işten doyum alma, hiyerarşik bir ortamda çalışma durumuna göre farklılaşmamaktadır ( $\mathrm{F}=1.727, \mathrm{p}=.183 ; \mathrm{F}=.656$, $\mathrm{p}=.658 ; \mathrm{F}=2.593, \mathrm{p}=.080 ; \mathrm{F}=3.020, \mathrm{p}=.053 ; \mathrm{F}=2.047, \mathrm{p}=.135$ ).

Tablo 4. Sosyal Adalet Savunuculuğu Yaparken Karşılaşılan Güçlükler

\begin{tabular}{|l|c|c|}
\hline Karşılaşılan güçlük konu başlı̆̆ı & (n) & (\%) \\
\hline Bürokrasi ve hiyerarşi & 22 & 24,44 \\
\hline $\begin{array}{l}\text { Kamu kurum ve kuruluşlarında direnç ile } \\
\text { karşılaşma }\end{array}$ & 13 & 14,44 \\
\hline Yasalar, mevzuat ve politika & 12 & 13,33 \\
\hline $\begin{array}{l}\text { Kaynak yetersizliği ve kaynaklara erişimde } \\
\text { güçlük }\end{array}$ & 8 & 8,88 \\
\hline Sistemin yavaş ve yetersiz olması & 5 & 5,55 \\
\hline $\begin{array}{l}\text { Kurum içinde de savunuculuk faaliyetleri } \\
\text { yürütmek zorunda olmak }\end{array}$ & 5 & 5,55 \\
\hline Toplum yapısı ve müracaatçı direnci & 5 & 5,55 \\
\hline Önyargı ve ayrımcı tutumlar & 5 & 5,55 \\
\hline $\begin{array}{l}\text { Sosyal hizmet mesleğinin bilinmemesi ve } \\
\text { alanda çalışan kişilerin mesleki yeterliliğinin } \\
\text { olmaması }\end{array}$ & 3 & 3,33 \\
\hline Dil bariyeri & 3 & 3,33 \\
\hline Diğer & 9 & 10 \\
\hline Toplam & 90 & 100 \\
\hline
\end{tabular}

Sosyal hizmet uzmanlarının dörtte üçü sosyal adalet savunuculuğu yaparken güçlüklerle karşılaştı̆̆ını belirtmiştir ( $n=75, \% 75)$. Sosyal adalet savunuculuğu yaparken güçlüklerle karşılaştıklarını belirten sosyal hizmet uzmanları bu güçleri şu şekilde belirtmiştir: Bürokrasi ve hiyerarşi (\%24.44), kamu kurum ve kuruluşlarında direnç ile karşılaşma (\%14.44), yasalar, mevzuat ve politika (\%13.33), kaynak yetersizliği ve kaynaklara erişimde güçlük (\%8.88), kurum içinde de savunuculuk faaliyetleri yürütmek zorunda kalınması (\%5.55), sistemin yavaş olması 
ve savunuculuk faaliyetlerini desteklememesi (\%5.55), toplumun sosyoekonomik, kültürel yapısı ve eğitim düzeyi ayrıca müracaatçının hakkının savunulmasını istememesi ve direnişte bulunması (\%5.55), alanda çalışan kişilerin mesleki yeterliliğinin olmaması, önyargı ve ayrımcı tutumlar (\%5.55), dil bariyeri (\%3.33), sosyal hizmet mesleğinin bilinmemesi ve değer görmemesi (\%3.33), mevzuat ve mevcut uygulamalar arasında farklılık olması, uygulamada yetersizlik ve belirsizlik olması, yabancı düşmanlığı gibi diğer güçlükler (\%10). 2016 yılında yayınlanan çocuk refahı alanında kamuda, sivil toplumda, özel sektörde ve belediyelerde çalışan sosyal hizmet uzmanlarının savunuculuk uygulamalarını inceleyen nitel bir araştırmada savunuculuk yaparken karşılaşılan güçlükler sorulduğunda benzer cevapların alınmış olduğu görülmüştür (Karabekir, 2016). Yine 2019 yılında yapılan bir çalışmada da sosyal hizmet uzmanları mesleğin tanınmadığını, kamu kurumlarında yöneticiler ve sosyal hizmet uzmanlarının üzerinde politik bir baskının olduğunu, iş yükünün fazla olduğunu, mevzuatta sinırlılıklar bulunduğunu ve bürokratik engeller olduğunu belirterek bunların hak savunuculuğu yapmayı engellediğini belirtmiş̧tir (Avşar, 2019:56). Farklı zamanlarda farklı kurumlarda gerçekleştirilen çalışmalarda benzer yanıtlar alınmasına önemlidir. Bu noktada sosyal hizmet uzmanları için nihai hedef olan sosyal adaleti sağlama ve bu hedefe ulaşmada aracı olan savunuculuk faaliyetlerinin bu durumlardan ne derece etkilendiği önemlidir. Bu çalışmada etkileyen etmenler üzerinde durulmamıştır. Ancak ortak olarak dile getirilen sorunlar göstermektedir ki içsel ve dışsal pek çok durumla mücadele eden sosyal hizmet uzmanları için sosyal adalet savunuculuğu yürütmek kolay değildir. Yine de karşılaşılan tüm güçlüklere rağmen araştırmada sosyal hizmet uzmanlarının sosyal adalet savunuculuğu düzeylerinin yüksek çıkmasının takdire şayan olduğu düşünülmektedir.

\section{SONUÇ ve ÖNERILLER}

Araştırmaya genel olarak bakıldığında sosyal hizmet uzmanlarının sosyal adalet savunuculuğu düzeylerinin yüksek çıkması memnuniyet vericidir. Sosyal hizmet uzmanlarının savunuculuk düzeylerinin sivil toplumda gönüllü faaliyetler yapma, mesleği kendi isteğiyle tercih etme, çalışılan sosyal hizmet alanı, alınan maaş, yaptığı işten doyum alma, hiyerarşik bir ortamda çalışma durumuna göre farklılaşmamaktadır. Bu durum sosyal hizmet uzmanlarının farklı durumlara rağmen yüksek savunuculuk becerileri sergileme noktasında ayrışmaması açısından önemlidir. Buna karşın sosyal adalet savunuculuğunun savunuculuk ile ilgili bir eğitim alma, sivil toplumda veya kamuda çalışma durumuna göre farklılaşması da önemlidir. Bu durum sosyal hizmet uzmanlarının sosyal adalet savunuculuğunun farklılaşmasına neden olan durumların üzerinde daha ayrıntılı durulması gerektiğini ortaya koymaktadır. Hangi durumların sosyal hizmet uzmanlarının sosyal adalet savunuculuk yetkinliklerini desteklediği hangilerinin sinırladığı konusunda daha detaylı bilgilere sahip olunursa sosyal hizmet uzmanlarının bu yetkinliklerini koruma ve geliştirme noktasında doğru uygulamalar geliştirilebilir. Çalışmamızın bu konuda bir başlangıç sunduğu düşünülmektedir.

Araştırma sonuçlarına ve tartışma bölümünde değinilen noktalara göre öneriler şu şekilde siralanabilir:

- Kamu kurum ve kuruluşları ile sivil toplum kuruluşlarında çalışan sosyal hizmet uzmanlarının sosyal adalet savunuculuğu düzeylerini etkileyen etmenler araştırılarak alanın ve sosyal hizmet uzmanlarının güçlendirilmesi ve iyileştirilmesine yönelik çalışmalar yürütülmelidir.

- Sosyal hizmet uzmanlarının sosyal/politik savunuculuk düzeylerinin artırılmasına yönelik çalışmalar gerçekleştirilmelidir. 
- Sosyal hizmet uzmanlarının alanda çalışma süresinin sosyal adalet savunuculuğunu etkilediği düşünüldüğünde sosyal hizmet uzmanları için yıpranma payının göz önüne alınması ve buna yönelik destekleyici ve geliştirici uygulamalar hayata geçirilmelidir.

- Sosyal hizmet uzmanlarının kurum içinde desteklenmesinin önemine yönelik farkındalık çalışmaları artırılmalıdır.

- Sosyal hizmet uzmanları toplumu ilgilendiren ve sosyal adaleti sağlama noktasında etkili olan politikalarda karar alma süreçlerine aktif olarak dahil edilmelidir.

- Sosyal hizmet ve sivil toplum alanı arasındaki ilişki, teoride olduğu kadar uygulamada da vurgulanmalıdır. Sosyal hizmet uzmanları sivil toplum kuruluşlarında daha aktif görev almalıdır.

- Sivil toplum kuruluşlarında gönüllü çalışmaların artmasına yönelik motive edici uygulamalar hayata geçirilmelidir.

- Araştırmaya özel sektörde çalışan sosyal hizmet uzmanları da dahil ederek daha büyük bir örneklemde çalışma tekrar edilmelidir.

\section{KAYNAKÇA}

Akgün, M. (2019). Toplum Ruh Să̆lığı Merkezinde Çalışan Sağlık Profesyonellerinin Bilgi, Beceri, Deneyim ve Görüşlerinin Değerlendirilmesi, Yüksek Lisans Tezi, Üsküdar Üniversitesi: İstanbul.

Avşar, M. K. (2019). Türkiye'de Sosyal Hizmet Uzmanlarının İstihdam Olanakları: Sorun Alanları ve Fırsatlar, Yüksek Lisans Tezi, Celal Bayar Üniversitesi: Manisa.

Aziz, A. (2014). Sosyal Bilimlerde Araştırma Yöntemleri ve Teknikleri. (9. Basım), Ankara: Nobel.

Büyüköztürk, Ş., Çakmak, E. K., Akgün, Ö.E., Karadeniz, Ş. ve Demirel, F. (2014). Bilimsel Araştırma Yöntemleri. (17. Basım), Ankara: Pegem Akademi.

Çağlıyan, E. (2018). Sosyal Hizmet Kurumu Çalışanlarında Tükenmişlik: Konya Örneği, Yüksek Lisans Tezi, Necmettin Erbakan Üniversitesi: Konya.

Dean, J.K. (2009). Quantifying Social Justice Advocacy Competency: Development of The Social Justice Advocacy Scale, Department of Counseling and Psychological Services, PhD Thesis, Atlanta: Georgia State University.

Duyan, V., Sayar, Ö. Ö. ve Özbulut, M. (2008). Sosyal Hizmeti Tanımak ve Anlamak. (1. Baskı), Ankara: Öncü.

Eren, G. S. (2019). Sosyal Hizmet Öğrencilerinin Sosyal Adalet Savunuculuğu Yetkinlikleri ile Çocuk İhmal ve İstismarına Bakış Açıları Arasındaki İlişkilerin İncelenmesi, Yüksek Lisans Tezi, Üsküdar Üniversitesi: İstanbul.

Ezell, M. (2001). Advocacy in the Human Services. (1st edition), USA: Brooks/ Cole.

Genç, B. (2019). Çocuk Refahı Alanında Çalışan Meslek Elemanlarının Psikolojik Dayanıklılıkları ve Baş Etme Tarzları, Yüksek Lisans Tezi, Hacettepe Üniversitesi: Ankara.

Hoefer, R. (2016). Advocacy Practice for Social Justice. (3rd edition), New York: Oxford University Press. 
https://www.ifsw.org/what-is-social-work/global-definition-of-social-work/ [Erişim Tarihi: 30.08.2020]

https://www.socialworkers.org/About/Ethics/Code-of-Ethics/Code-of-Ethics-English [Erişim Tarihi: 30.08 .2020$]$

Kalaycı, E. (2016). Sosyal Hizmet Öğrencilerinin Sosyal Adalet Savunuculuğu Yetkinlikleri İle LGBTí Bireylere Yönelik Tutumları Arasındaki İlişkinin İncelenmesi, Yüksek Lisans Tezi, Ankara Üniversitesi: Ankara.

Kara, Y. (2019). Makro Sosyal Hizmet Çerçevesinde Sivil Toplum Kuruluşlarının Önemi, Sosyal Bilimler Dergisi, 4(2): 155-169.

Karabekir, H.M. (2010). Yetiştirme Yurdu Örneğinde Sosyal Hizmet Uzmanlarının Sosyal Hizmet Değerlerini Mesleki Uygulamalarına Aktarışı, Yüksek Lisans Tezi, Hacettepe Üniversitesi, Ankara.

Karabekir, H.M. (2016). Çocuk Refahı Alanında Çalışan Sosyal Hizmet Uzmanlarının Savunuculuk Uygulamaları: Bir Niteliksel Araştırma, Doktora Tezi, Hacettepe Üniversitesi: Ankara.

Karadağ, E.Y. (2017). Sosyal Hizmet Disiplini ve Sivil Toplum İlişkisi, Yüksek Lisans Tezi, Üsküdar Üniversitesi: İstanbul.

Karasar, N. (1995) Bilimsel Araştırma Yöntemi. (7. Baskl), Ankara: 3A Araştırma Eğitim Danışmanlık.

Kesgin, B. (2016). Kamu Sorumluluğunda Sosyal Hizmet. (2. Baskı), İstanbul: Açılım Kitap.

Koç, S.Ç. (2015). Sosyal Hizmet Uzmanlarını Sorun Çözme Becerileri Üzerine Bir Araştırma, Yüksek Lisans Tezi, Hacettepe Üniversitesi: Ankara.

Lewis, J., Arnold, M.S., House, R., Toporek, R.L., and Daniels, J. (2018). American Counseling Association Advocacy Competencies. https://www.counselingcsj.org/uploads/1/2/3/6/123630265/aca-2018-advocacy-competencies.pdf [Erişim Tarihi: 30.08.2020]

Mancılık, A. (2015). Sosyal Hizmet Öğrencilerinin Müracaatçı Olarak Yaşlılarla Çalışma ve Yaşlılara Yönelik Tutumlarının Belirlenmesi, Yüksek Lisans Tezi, Ankara Üniversitesi: Ankara.

Mosley, J.E. (2010a). Organizational Resources and Environmental Incentives: Understanding the Policy Advocacy Involvement of Human Service Nonprofits, Social Service Review, 84(1): 57-76.

Mosley, J.E. (2010b) The Policy Advocacy Role of Human Service Nonprofits: Incentives, Involvement, and Impact, (Editör) Hasenfeld, Y.: Human Services as Complex Organizations içinde (ss.503-532) (2nd edition), USA: Sage Publications.

Mosley, J.E. (2011). Institutionalization, privatization, and political opportunity: What tactical choices reveal about the policy advocacy of human service nonprofits, Nonprofit and Voluntary Sector Quarterly, 40(3): 435-457. 
Nilsson, J. and Schmidt, C. (1970). Social Justice Advocacy Among Graduate Students in Counseling: An Initial Exploration, Journal of College Student Development, 46: 267-279.

Parsons, R.J. (1991). Empowerment: Purpose And Practice Principle in Social Work, Social Work With Groups, 14(2): 7-17.

Prior, K. and Quinn, S. (2012). The Relationship Between Spirituality and Social Justice Advocacy: Attitudes of Social Work Students, Journal of Religion \& Spirituality in Social Work: Social Thought, 31(1-2): 172-192.

Ratts, M.J., DeKruyf, L. and Chen-Hayes, S.F. (2007). The ACA advocacy competencies: A social justice advocacy framework for professional school counselors, Asca I Professional School Counseling, 11(2): 90-97.

Reamer, F.G. (2018). Sosyal Hizmet Etiği ve Değerleri, (Çeviren Acar, H.) Ankara: Nika Yayınevi.

Reçber, B. (2018). İnsan Hakları ve Sosyal Adalet Açısından Devletin Çocuklara ve Kadınlara Yönelik Sunduğu Hizmetler: Aile Ve Sosyal Politikalar Bakanlığı Çalışanları Örneği, Doktora Tezi, Uludağ Üniversitesi: Bursa.

Rwomire, A. (2011). The Role of Social Work in National Development, Social Work and Society, 9(1): 108-118.

Serpen, A.S., Duyan, V. ve Aldoğan, E.U. (2014). Sosyal Adalet Savunuculuğu Ölçeği Güvenirlik ve Geçerlik Çalışması, Toplum ve Sosyal Hizmet, 25(1).

Sheafor, B.W. ve Horejsi, C.J. (2014) Sosyal Hizmet Uygulaması Temel Teknikler ve İlkeler (Çeviren, Çiftçi D.B.) Ankara: Nika Yayınevi.

Sunal, O. (2011). Sosyal Politika: Sosyal Adalet Açısından Kuramsal Bir Değerlendirme, Ankara Üniversitesi SBF Dergisi, 66(3):283-305.

Toporek, R.L, Lewis, J.A. and Crethar, H.C. (2009). Promoting systemic change through the ACA advocacy competencies, Journal of Counseling \& Development, 87: 260-268.

Zastrow, C. (2015). Bir Meslek ve Uzmanlık Alanı Olarak Sosyal Hizmet, (Çeviren Çiftçi, D.B.) Ankara: Nika Yayınevi. 